\title{
Å se et annet menneskes smerte er å forpliktes moralsk
}

Den norske filosofen Arne Johan Vetlesen har skrevet en bok om smerte, Smerte $i$ vår tid. Det er ikke en bok om smerte slik vi som sykepleiere vanligvis forstår smerte.

\section{Per Nortvedt}

Professor emeritus

Senter for medisinsk etikk, Universitetet i Oslo

Smerte Smertebehandling Bokkommentar

Sykepleien 2021109 (86168) (e-86168)

DOI: 10.4220/Sykepleiens.2021.86168

I sykepleien og i den tradisjonelle biomedisinske forståelsen av smerte er man opptatt av forbindelsen mellom den enkeltes hjerne, kropp og opplevelse. Smerte er både et symptom og en diagnose (1).

I Vetlesens bok (2) er det få helsefaglige perspektiver på smerte i en mer snever biomedisinsk forstand. I stedet viser han hvordan smerte er et fenomen med mange dimensjoner. Vetlesen opprettholder en forståelse av smerte som fysisk og psykisk, men han sier egentlig lite om den fysiske smerten i boken. Samtidig sier han at disse to sidene ved smerte ikke kan ses atskilt fra hverandre.

LES: \#Smertevurdering 
Det er en viktig påpekning, for i dag forstås smerte som både en flerdimensjonal og en personlig opplevelse. Vetlesen belyser smerte filosofisk og etisk. Smerte diskuteres via empatiteori og psykologi, via ondskapsforskning, kulturforståelse og i et samfunnsvitenskapelig perspektiv.

Smerte kan forstås som smerte i kulturen og i det Vetlesen kaller opsjonssamfunnet. Opsjonssamfunnet gjør valgfriheten til en tvangstrøye med krav om at borgeren alltid må velge, alltid må omstille seg og tilpasse seg stadig nye krav for å realisere seg selv.

Smerte kommer også til uttrykk som kulturell vold, gjennom realitysjangerens og massemedienes voldsomme eksponering av individuell konkurranse og kamp om selvrealisering og herredømme over andre.

\section{Ønsker man alltid å unngå smerte?}

«Uten smerte er livet vårt ikke til å leve. Med smerte er livet knapt til å holde ut», er ordene som åpner et av de første kapitlene i Vetlesens bok (2, s. 17).

Første del av utsagnet kan forstås biomedisinsk og er som sådan ganske plausibelt. Som helsepersonell vet man at smerte er et av de viktigste signalsystemene vi har, som varsel på skade, vevsødeleggelse og fare.

\section{«Hva da med mennesker som med hensikt påfører seg smerte gjennom askese.»}

Personer som er født uten smertesans, må konstant overvåkes og vernes mot seg selv. De kan få store brannskader eller blø i hjel uten å merke det.

Men forstått eksistensielt er kanskje denne delen av utsagnet ikke så intuitivt innlysende. Ville vi ikke alle ha $\varnothing$ nsket et liv uten psykisk smerte, engstelse, sorg, bekymring, hvis man kan regne dette som smerte? Er ikke smerte noe man alltid ønsker å unngå? 
Men hva da med mennesker som med hensikt påfører seg smerte gjennom askese, eller på ulike måter ønsker å «lutres», idet de mener at smerte og lidelse har en rensende effekt. Idrettsfolk kan også se det å utholde en grad av smerte som en del av prestasjonen - for eksempel at melkesyreterskelen er et tegn på at man kan nå målet, men at dette er en terskel som heller ikke må overskrides.

\section{Smerte er et grunnvilkår}

Smerte er også en del av våre liv som et eksistensielt grunnvilkår, som en betingelse for vår sameksistens med andre mennesker. Forståelse av disse grunnvilkårene har preget mesteparten av Vetlesens forfatterskap, og de er sentrale i hans forståelse av smerte som en følelse, som noe vi opplever, som vi preges av.

De ufravikelige grunnvilkårene som avhengighet, sårbarhet, dødelighet, relasjoners skjørhet og eksistensiell ensomhet former våre liv og våre erfaringer. Disse grunnvilkårene viser oss smertens dobbelthet, dens janusansikt:

«Smerte er et fenomen som splitter og $\varnothing$ delegger, men samtidig kan smerte også være en samlende kraft slik det kommer til uttrykk når den enkelte mobiliserer hele sin livsvilje i kampen for å normalisere sin tilværelse.» (1, s. 25)

Å kunne føle og forstå andres smerte er en fundamental betingelse for det å være medmenneske, å kunne sameksistere med andre.

Men smerte kan ramme oss selv, som et lyn utenfra, ved skade, ved traume og sykdom. Erfaringen av smerte gjør at våre sanser innskrenkes: 
«Smerte, sluker alt i randsonen for vår

oppmerksomhet, lukker sansene, idet all

oppmerksomhet trekkes mot smerten selv. Sansene

åpner verden for oss og gjør at vi kan se den tydeligere.

I smerten innskrenkes blikket. Man ser, men man ser

likevel ikke, fordi man ikke orker å være oppmerksom.

Det å leve i smerter skaper avstand til alt annet $\mathrm{i}$ menneskets verden enn smerten selv. Smerte gir ikke rom for annet enn seg selv. Den fortærer enhver foretaksomhet og enhver åpenhet som ikke er rettet mot selvet.» (3, s. 61-62)

Dette skriver vi om smertens fenomenologi i boken Smerte - fenomen og etikk. Vetlesen følger opp: «Smertefullheten skaper avstand til alt annet enn smerten selv. Smerten er som en magnet som trekker all oppmerksomhet, all energi mot seg.» (2, s. 69)

\section{Hvordan er det å leve med smerter?}

Denne måten å forstå smerte på skiller seg radikalt fra den tradisjonelle biomedisinske forståelsen av smerte som årsaksforklaring, søken etter fysiologiske mekanismer og behandlingsmodeller for smertelindring. Vi snakker her om å forstå opplevelsen av smerte fra pasientens subjektive perspektiv.

Et slikt perspektiv på smerte som fenomen er særlig viktig for de yrkene som arbeider med mennesker med smerter, akutte så vel som kroniske. En sykepleier som arbeider med kroniske smerter, for eksempel i rehabilitering, må ha en forståelse for hvordan det føles, dag ut og dag inn, å leve med mer eller mindre konstante smerter, hvordan det stjeler all energi og oppmerksomhet, og hvilken personlig og psykisk belastning det er for pasienten selv og dem rundt ham eller henne.

\section{«Medisinen og sykepleien er yrkene der man møter andre menneskers smerte i mange dimensjoner og i stor utstrekning.»}


En lege ved en kirurgisk avdeling må forstå hvordan hans eller hennes handlinger kan forårsake smerter ved inngrep og prosedyrer, og gjøre det som er mulig for å unngå un $\varnothing$ dig å påføre pasienten smerter - for eksempel ved ikke å starte et inngrep for lokalanestesien har virket, eller enda viktigere, ikke å fjerne et toraksdren uten bedøvelse på en våken og bevisst pasient.

Selv om Vetlesen skriver lite om smerte i medisinen og sykepleien, er dette de yrkene der man møter andre menneskers smerte i mange dimensjoner og i stor utstrekning, og der man har som en viktig oppgave å avhjelpe og lindre andres smerte (3).

I sykepleien brukes alle innfallsvinkler til å lindre og bistå i behandlingen av andre menneskers smerte. Man behandler smerte medikamentelt, ved å stimulere gjennom avledningsmetoder og psykoedukative tilnærminger. Man hjelper pasienten til å mestre egne smerter, og til i verste fall, ved kroniske smerter, å leve med smertene.

\section{Pasientens er pleierens bør}

Skal man i sykepleien følge opp det brede perspektivet på smerte som Vetlesen anlegger i Smerte $i$ vår tid, kan man si at sykepleiens perspektiv på smerte må være både biomedisinsk, filosofisk/etisk, kulturelt og samfunnsvitenskapelig. Men i sykepleien og særlig i medisinen har forståelsen av smerte som en subjektiv erfaring liten plass, både i klinikk og i forskning.

Det er også sparsomt med forskning på de moralske dimensjonene og etiske problemstillingene som reises i smertebehandling. Dette er rart, fordi det $\mathrm{i}$ sykepleiefaget ellers finnes mye forskning på pasienters og pårørendes opplevelser, og fordi også sykepleiens historiske tradisjon særlig betoner en forståelse av pasientens erfaringer som syk som grunnleggende for å beskrive hva sykepleie er (4). 


\section{«Forståelse av smerte som fenomen innebærer at man blir følelsesmessig affisert av personens ubehag og smerte.»}

Kari Martinsen har, som Vetlesen i sitt forfatterskap, satt ord på de moralske dimensjonene ved smerte - at det å preges av en annens smerte er å forpliktes moralsk. «Pasientens er pleierens bør», sier hun $\mathrm{i}$ boken Fenomenologi og omsorg - tre dialoger fra 1996 (5). Hun uttrykker dermed en form for moralsk realisme, at man erfarer situasjoner i pleien av den syke som etisk ladet.

Det dreier seg også om en bestemt måte å forstå på, der man lar seg fange av den andres perspektiv og erfaringer. Å se et annet menneskes smerte er å forpliktes moralsk; men det forutsetter at man lar seg berøre, at man har empati.

Forståelse av smerte som fenomen - i sykepleien som i livet ellers - innebærer ikke bare at man kan forstå hva smerte innebærer for pasienten, men også at man blir følelsesmessig affisert av personens ubehag og smerte.

Dette er noe Vetlesen og undertegnede har vært særlig opptatt av. I boken Følelser og moral fra 1996 skriver vi:

«Vi kan si at følelser har det første ordet: de er verdensåpnende, de vender vår oppmerksomhet $-i$ vid forstand, ikke snevert kognitivt - mot situasjonen, mot de trekkene ved situasjonen som berører oss umiddelbart. Følelser forankrer oss til den enkelte moralske omstendighet.» (6, s. 69)

\section{Smerte skapes i samfunnet}

Man kan ikke forvente at sykepleiefaget skal ha en filosofs brede perspektiv på smerte, på samme måte som en filosof ikke har det praktiske og biomedisinske blikket på å lindre smerte. 
Men kanskje kan begge lære noe av hverandre: Sykepleien som fag kan se hvordan smerte i vid forstand videreføres og skapes i samfunnet, i kulturen og politikken, og filosofen kan få en mer praktisk forståelse av hvordan smerte ved hjelp av ulike verktøy og metoder kan lindres.

\section{Referanser}

1. Nortvedt F, Ljoså T-M. Smerte - en personlig og sammensatt opplevelse. I: Kristoffersen NJ, Skaug E-A, Steindal SA, Grimsb $\varnothing$ GH, red. Grunnleggende sykepleie. 4. utg. Bind 3. (Under utgivelse.) Oslo: Gyldendal Akademisk; 2021.

2. Vetlesen AJ. Smerte i vår tid. Lysaker: Dinamo forlag; 2020.

3. Nortvedt P, Nortvedt F. Smerte - fenomen og etikk. Oslo: Gyldendal Akademisk; 2018.

4. Nortvedt P. Omtanke. Innføring i sykepleieetikk. Oslo: Gyldendal Akademisk; 2021.

5. Martinsen K. Fenomenologi og omsorg - tre dialoger. Oslo: Universitetsforlaget; 1996.

6. Vetlesen AJ, Nortvedt P. Følelser og moral. Oslo: Ad Notam Gyldendal forlag; 1996. 